\title{
CORRESEONDENTCE.
}

\section{RAILWAY SECTIONS IN AYRSHIRE AND LANARKSHIRE.}

Sin,-At present there are some railway sections through Drift in the line being constructed from Darvel, in Ayrshire, to Strathavon, in Lanarkshire, which, I think, show features demonstrative of a depression of the land, and the marine origin of at least part of the Drift beds. Lately, with two friends (it was my fourth visit to the locality), I examined minutely one of these sections, 500 to 600 feet above sea-level (estimated from a bench-mark). This cutting is to be a deep one, and is being taken in two 'lifts'; about 200 yards of the upper lift can at present be examined, but it is much longer, part of the slope being already pick-dressed. The section is almost horizontal for the above-mentioned distance, and very regular-not at all twisted or disturbed, as is the case with many parts of the Drift. It is about two miles east of Darvel. The following beds are exposed :-

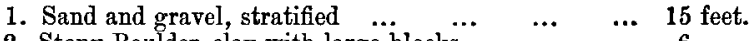

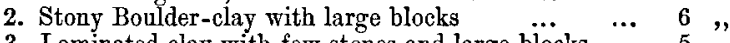
3 . Laminated clay with few stones and large blocks $\ldots .5$,"

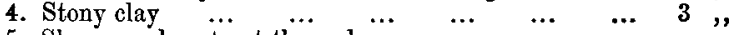
5. Sharp sand, not cut through.

In bed 1, I observed a long boulder of Matstone Hill granite, quite in a vertical position. In beds 2,3 , and 4 , long boulders were obtained during the progress of the cutting, in a similar position. In the laminated bed 3, a large striated boulder of white sandstone is at present to be seen, measuring four feet in diameter. It has clearly fallen into the clay when the latter was in a soft state, as the laminæ at the bottom corners of the block are bent down under it, showing that the block in falling has made a small indent in the laminated clay. They (the laminæ) also curved over the top of the block.

Another interesting feature was the depressions or ruts in the stony clay bed 2 , these being invariably filled more or less with laminated clay. A number of shell-fragments with the epidermis were picked out by us from the stony clay, and from the laminated bed we secured a perfect valve of Leda parvula. (I may say that in this district marine shells are frequent in certain parts up to 700 feet above sea-level. See suppl. to vol. xi, Trans. Geol. Soc. Glasgow, p. 59.)

The boulders in the sections of the railway at this part are a variety of porphyrites (igneous rocks with conspicuous felspar, a 'Survey' term), amygdaloids, felstones (igneous fine-grained rock, a 'Survey' term), sandstones, dolerites, a few limestones; Matstone Hill granite, a moderately coarse-grained reddish granite, being not infrequent, the parent rock occurring fully two miles to the south and on the opposite side of the Irvine Valley to the railway sections.

Not only the Boulder-clay, but a sharp grey sand bed also shows very distinct jointing. The joints in a sand-pit 200 yards north of the railway were very conspicuous, and had attracted the attention of the workmen in the pit, who called them water-backs. Workmen's 
terms are generally pretty expressive. In solid rocks water often issues from joints.

We went on to Londoun Hill. This hill is not named on Sheet 23; it is just above the house named Backhill on the western edge of the map. It is composed of large vertical columnar felstone.

To the east and south-east of this bill the 'Survey' have shown a 'terrace of marine drift' and an 'old sea beach.' Lately I observed that the talus of large blocks from the hill had fallen down upon the top of the 'marine drift,' so that the great vertical cliff on the south side of the hill was very likely the work of the vaves, assisted perhaps by shore-ice, for much of the 'felstone' in the drift may have come from this hill, it being the only felstone rock within many miles of this district.

The 'marine terrace' is 700 feet, and the top of Londoun Hill 1,034 feet, above sea-level.

The facts given in this letter speak, I think, pretty plainly. The Drift beds here are clearly water deposits, and that 'water' was the sea. The blocks and stones in both the stony and laminated clay were clearly dropped into the clay from floating ice. In bed 2 (the stony Boulder-clay), there are frequent indications of stratification, and those lines have a steady, gentle dip of five to ten degrees towards the east, or up the Irvine Valley. This long section has been exposed to the weather for about six months; the clay has not slipped, and the rain-washed face of the drift can be read like a book. There are many well-striated stones and boulders lying in all directions, long ones even vertical, but quite as many which show no striations. The ruts in the stony clay bed 2 were probably produced by floating ice grating on the sea bottom, and these have formed sheltered hollows in which laminated clay has been deposited.

MonkReding, KiLWinnima.

J. Sмiтн.

\section{SOME SNOWDON TARNS.}

SIR,-Will you permit me to correct a mistake in my paper on "Some Snowdon Tarns." The depression at 250 yards from the present outlet of Llyn Llydaw is in a N.N.E. direction therefrom, not N.N.W. as I had erroneously written.

Snowdon Vigw, Nant Gwrant,

Beddgelert, Carnarton.

February 19, 1900.

J. R. DAKINS.

\section{OAITUARY. \\ GEHEIMRATH PROFESSOR DR. GEINITZ, \\ For. MEM. Geol. Soc. Lond. \\ Born October 16, 1814.}

Dr. Hans Brono Gerinz was born at Altenburg, Saxony, where be passed a happy boyhood in his father's home. The political troubles of 1830 affected the family prosperity, so that the youthful 